\title{
Towards an International History of the Nineteenth-Century Art Trade
}

\author{
Jan Dirk Baetens and Dries Lyna
}

In 1920 the prestigious French Légion d'honneur was awarded to the art dealer Paul Durand-Ruel, whose clever business tactics had launched the careers of the impressionists a few decades earlier. The reason for this official mark of honour was not so much Durand-Ruel's role in the flowering of French art as such, as it was his contribution to foreign trade. ${ }^{1}$ This motivation was probably not a surprise for the dealer. Commercial success abroad had been essential in the impressionists' rise to fame: as Durand-Ruel himself observed in his memoirs, it was only after he had been able to secure a firm footing for impressionist art abroad-especially in the United States-that it became a subject of appreciation in France. ${ }^{2}$ Such a dynamic of foreign success as a catalyst (or even a precondition) for success in the home-market is by no means unique to impressionist art, or even to art in general. However, the need for and the beneficial effects of such a detour are striking for a type of painting that was quick to be considered as quintessentially French and also marketed as a very "national" kind of art.

Yet Durand-Ruel's international promotion of an apparently very "national" kind of art is less singular than it may appear at first sight. In fact, on closer inspection, it seems characteristic of much of the international expansion of the art market in the course of the "long" nineteenth century as a whole: not only did it become increasingly easy and common for works of art, dealers, artists and collectors to cross national borders in search of new markets as the century progressed, but this internationalisation of the market often also involved the conceptualisation and mobilisation of notions and modes of thinking closely tied to ideas about national identity.

During the nineteenth century continuing improvements to the roads and transportation infrastructure ensured that the local art markets in Europe became connected like never before, both in the proverbial and literal senses of

1 Paul Durand-Ruel, Memoirs of the First Impressionist Art Dealer (1831-1922) (Paris: Flammarion, 2014), 164.

2 Id., 158.

(C) JAN DIRK BAETENS AND DRIES LYNA, 2019 | DOI:10.1163/9789004291997_002

This is an open access chapter distributed under the terms of the prevailing CC-BY-NC License at the time of publication. 
the word. Art and antiques increasingly found new destinations in private and public collections abroad, while more and more artists, amateurs and art dealers roamed the European continent - and beyond — in their never-ending pursuit of aesthetic pleasure and/or commercial benefit. Information networks equally tightened, allowing dealers and collectors to communicate easily across wide distances and at the same time stay close to the pulse of art scenes far away. The painting depicted on the cover of this book, Giuseppe de Nittis's The National Gallery of 1877 , seems to summarise much of this state of affairs. De Nittis was an Italian who moved to Paris and worked for much of his career for the multinational Goupil dealership. In 1874, however, he started undertaking annual trips to London, where he sought a new market and was aided in these efforts by the expatriate French artist James Tissot. Like Tissot, De Nittis was interested in typically British scenes, which he presented from his outsider point of view as a foreigner. One of his subjects for a series of twelve paintings made for a British collector was the National Gallery, one of the main tourist attractions in London, which he showed with its throng of local and foreign visitors on the pavement in front of it showcasing the dynamic flux of modern life surrounding it. ${ }^{3}$ Eight of these very British scenes made by an Italian artist living in France were exhibited at the universal exhibition of $1878 .{ }^{4}$

The internationalisation of European art worlds was closely intertwined with the growing importance of the very conceptual categories and modes of thinking that this integration seemed to question: artistic or commercial labels referring to nationality and structures of knowledge based on distinctions grounded in national identity, most conspicuously articulated in the division of art production into separate national "schools" in (popular) art-historical literature, art criticism, early museum catalogues, auction catalogues, and catalogues of contemporary art exhibitions and commercial galleries. Thus, major art dealers imported thousands of paintings from abroad, but often pitched them as typical examples of a national school; universal exhibitions introduced foreign artists to local markets, but were also based on a logic of emulative competition along national lines; and artists often sought patronage abroad, either nurturing the taste for the foreign in other countries or adapting their own work to foreign taste.

The aim of this volume is to study the development of the nineteenthcentury art market along these two crucial axes of nationalism and internationalism. More specifically, it examines the international expansion and

3 Caroline Corbeau-Parsons, ed., Impressionists in London: French Artists in Exile 1870-1904 (London: Tate, 2018), 109.

4 Id., 209. 
gradual integration of art markets and the ways in which this process was connected to the steady—or, rather, steadily growing — emphasis on categories, concepts and modes of thinking related to national identity in the matrix of art knowledge accompanying it. This book therefore raises the central question how the integrating European art market of the "long" nineteenth century (1750-1914) simultaneously countered and constructed notions and modes of thinking tied to national identity and how the various operators in the art market contributed and responded to them.

\section{The Internationalisation of Art Worlds}

The internationalisation of the art market was, of course, hardly an evolution specific to the nineteenth century. Already in the early modern era, important steps were taken towards expanding the art markets of European cities across supra-regional and proto-national borders. The export-oriented art market of Antwerp, for example, branched out to Paris from 1570 onwards, and three generations later specialist firms, such as Musson and Forchondt, explored markets in Central Europe, the Iberian Peninsula and even the Spanish Americas. ${ }^{5}$ Frequently informed of the local markets' pulse or demand by their agents (often family), these firms were able to deliver low- and middle-end art to new buyers abroad. In mid-seventeenth-century Amsterdam, gentleman-dealers such as Johannes de Renialme and Hendrick Uylenburgh dealt with Frederick William, ruler of Brandenburg-Prussia, while Uylenburgh's son Gerrit expanded the family business internationally with agents in every major European city. ${ }^{6}$ From the 1720 onwards, British artist-dealers such as Andrew Hay, Arthur Pond and John Blackwood crossed the Channel to replenish their stock for art

5 Filip Vermeylen, "À la recherche de l'art vendu: la diffusion de la peinture flamande en France (16ième-18ième siècle)," in Collectionner dans les Flandres et la France du Nord au XVIII ${ }^{e}$ siècle, ed. Sophie Raux (Lille: Université Charles-de-Gaulle-Lille, 2003), 128-30; Neil De Marchi and Hans Van Miegroet, "Novelty and Fashion Circuits in the Mid-SeventeenthCentury Antwerp-Paris Art Trade," Journal of Medieval and Early Modern Studies 28, no. 1 (1998): 201-46; Mickaël Szanto, "Antwerp and the Paris Art Market in the Years 1620-1630," in Mapping Markets for Paintings in Europe, 1450-1750, eds. Neil De Marchi and Hans J. Van Miegroet (Turnhout: Brepols, 2006), 329-42; Sandra van Ginhoven, Connecting Art Markets: Guilliam Forchondt's Dealership in Antwerp $\left(c .163^{2-78)}\right.$ and the Overseas Paintings Trade (Boston: Brill, 2016).

6 Friso Lammertse and Jaap van der Veen, Uylenburgh \& Son: Art and Commerce from Rembrandt to De Lairesse 1625-1675 (Zwolle: Waanders, 2006); John Michael Montias, Art at Auction in Seventeenth-Century Amsterdam (Amsterdam: Amsterdam University Press, 2002), $130-43$. 
auctions in London. ${ }^{7}$ Around the same time the French dealer-auctioneer Edme-François Gersaint travelled north to acquire Flemish and Dutch old masters to fuel his Parisian picture sales. ${ }^{8}$ In the late eighteenth century, the Austrian Netherlands were a crucial transit region with Brussels at its core, connecting the French, Dutch, English and even the emerging German markets. ${ }^{9}$

However, while the integration of the nineteenth-century European art market was clearly anticipated in earlier centuries, concepts of national identity hardly played a role in this. It was only in the last decades of the eighteenth century that these concepts began to be developed and could be deployed to further expand markets across national borders. The categorisation of art in national schools, for instance, was only a mid- to late eighteenth-century invention at best. It took until $175^{1}$ before Parisian auction catalogues began to consider this systematic approach, and even these early categorisations were far from exact, especially when it came to northern paintings. ${ }^{10}$ Popular art-historical publications followed similar patterns and suffered from comparable flaws. The title of the influential collection of artists' biographies La vie des peintres flamands (1753-64) by Jean-Baptiste Descamps suggests a focus on a specific (proto-national) school, but Descamps in fact discussed Dutch and not Flemish painters. His contemporary Antoine Joseph Dézallier d'Argenville's Abrégé de la vie des plus fameux peintres (1745-52) lumped together Flemish, Dutch, German and even English painters under the flag

7 David Ormrod, "Dealers, Collectors and Connoisseurship in Seventeenth \& EighteenthCentury London 1660-1760," in Kunstsammeln und Geschmack im 18. Jahrhundert, ed. Michael North (Berlin: Berliner Wissenschafts-Verlag, 2002), 17.

8 Guillaume Glorieux, À l'enseigne de Gersaint: Edme-François Gersaint, marchand d'art sur le pont Notre-Dame (1694-1750) (Seyssel: Champ Vallon, 2002); Neil De Marchi and Hans J. Van Miegroet, "Transforming the Paris Art Market, 1718-1750," in Mapping Markets for Paintings, 391-402.

9 Dries Lyna, "Towards an Integrated Market? The Austrian Netherlands and the Western European Trade in Pre-Owned Paintings," in Moving Pictures: Intra-European Trade in Images, 16th-18th Centuries, eds. Neil De Marchi and Sophie Raux (Turnhout: Brepols, 2014), 277-88.

$10 \quad$ Krzystzof Pomian, "Marchands, connaisseurs, curieux a Paris au XVIII e siècle," Revue de l'art 43 (1979): 23-36; Patrick Michel, "French Collectors and the Taste for Flemish Painting During the Eighteenth Century," in Art Auctions and Dealers: The Dissemination of Netherlandish Art During the Ancien Regime, eds. Dries Lyna, Filip Vermeylen, and Hans Vlieghe (Turnhout: Brepols, 2009), 127-37. 
"école flamande."11 A 1777 Flemish instruction book for art aficionados drew in Dutch artists in its own Flemish "national" category and informed its readers of the other (according to him) five schools of painting in existence (Roman, Venetian, Lombard, German and French). ${ }^{12}$ It was not until 1778 that a French auction catalogue finally made the distinction between the Flemish and Dutch schools of painting. ${ }^{13}$ So while the internationalisation of the European art market was well underway, the concept of national schools had not yet fully crystallised in the art world of the eighteenth century, let alone come to full maturity, in scholarly, commercial or popular artistic discourses. It was only when this mode of thinking developed and, eventually, came to structure systems of art knowledge in a defining way, that the internationalisation of the market further evolved.

If the international mobility of art, artists, dealers and collectors was not a new phenomenon proper to the nineteenth-century art market, it did not diminish in the twentieth century either. However, with the wake of twentiethcentury modernism, the discursive structure that accompanied and facilitated transfers and exchanges across borders did change in a fundamental, if gradual, way. In the late nineteenth and early twentieth centuries, nationally defined ideas and categories increasingly lost their explanative power or even their relevance, as secessionist movements and the commercial agents behind them all over Europe increasingly adopted 'a pan-European [...] Weltanschauung' in their 'search for a trans-national cultural identity,' as Robert Jensen has argued..$^{14}$ Ultimately, this led to a discursive de-nationalisation of (advanced) art in favour of a universalist modernist view and thus to a 'process whereby national and regional styles were swept away in favour of a hegemonic, unitary history of modern art.'15 This is not to say that national discourse or national labels became completely invisible in the twentieth century. Nationalism was back with a vengeance in the discourse surrounding French cubism, Italian futurism and German expressionism, to name only the most obvious examples. ${ }^{16}$

11 Bart Cornelis, “Arnold Houbraken's Groote Schouburgh and the Canon of SeventeenthCentury Dutch Painting," Simiolus: Netherlands Quarterly for the History of Art 26, no. 3 (1998): 154-5. Anon., Nieuwen almanach der konst-schilders, vernissers, vergulders en marmelaers, (Ghent: s.n., [c. 1777]), 144.

13 Pomian, "Marchands, connaisseurs, curieux," 23.

14 Robert Jensen, Marketing Modernism in Fin-de-Siècle Europe (Princeton: Princeton University Press, 1994), 5 .

$15 \quad I d ., 6$.

16 Ibid. 
Nevertheless, the importance of national identity in systems of art knowledge steadily declined as modernism rose internationally. With the final bankruptcy of nationalist ideologies after World War II, the significance of national labels became all but obsolete in the art world. Presently, national labels play a much more modest role in the art market. Old master paintings or nineteenthcentury works of art are still often related to their national schools in auction catalogues and in the art trade in general. In the globalised contemporary art scene, however, such a logic has largely disappeared in favour of a cosmopolitan or transnationalist paradigm.

\section{Two Sides of the Same Coin?}

The last decade has witnessed a mounting scholarly interest in the history of the art market of the "long" nineteenth century. This has resulted in the development of digital databases and other research tools, exhibitions on dealers, and dozens of publications concerned with various aspects of the art market or, rather, the markets for art in the nineteenth century. ${ }^{17}$ Most of these studies, however, have adopted a predominantly national perspective, delineating their field of research along national lines and usually dealing with the international dimension only from the perspective of a specific national framework. ${ }^{18}$

17 The stockbooks and other archival documents of Goupil, Knoedler and the Duveen Brothers have been digitised by the Getty. The Netherlands Institute for Art History is digitising the archives of Goupil's the Hague branch. Other examples of digital databases include the Archives Directory for the History of Collecting in America of The Frick Collection and Art Reference Library, the Salons et expositions de groupes 1673-1914 database of the Musée d'Orsay and the London Gallery Project of Bowdoin College. Recent exhibitions on art dealers include Kunsthandel Frans Buffa \& Zonen, 1790-1951. Schoonheid te koop (2016-17, Laren, Singer Laren); Paul Durand-Ruel. Pari de l'impressionisme (201415, Paris, Musée du Luxembourg, London, National Gallery, Philadelphia, Philadelphia Museum of Art), Picasso, Léger, Masson: Daniel-Henry Kahnweiler et ses peintres (201314, Villeneuve-d'Ascq, LaM), De Cézanne à Picasso. Chefs-d'œuvre de la galerie Ambroise Vollard (2006-7, Paris, Musée d'Orsay, New York, Metropolitan Museum of Art, Chicago, Art Institute); Gérôme \& Goupil: Art and Enterprise (2001, Bordeaux, Musée Goupil, New York, Dahesh Museum of Art, Pittsburgh, Frick Art \& Historical Center); and Theo van Gogh: Art Dealer, Collector, Vincent's Brother (1999-2000, Amsterdam, Van Gogh Museum, Paris, Musée d'Orsay).

18 See for instance: Thomas M. Bayer and John R. Page, The Development of the Art Market in England: Money as Muse, 1730-190o (London: Pickering \& Chatto, 2011); Pamela Fletcher and Anne Helmreich, eds., The Rise of the Modern Art Market in London, 1850-1939 (Manchester - New York: Manchester University Press, 2011); Monica Preti-Hamard and Philippe Sénéchal, eds., Collections et marché de l'art en France 1789-1848 (Rennes: Presses universitaires de Rennes, 2005). 
This can hardly be a surprise. Art history itself is still often written along national lines and has been so from its very inception as an academic discipline in the nineteenth century, the great age of nation states. Neither is this something to be rejected out of hand. Indeed, the epoch's own obsession with national identity may very well suggest the validity of national borders as lines of demarcation for a modern study of the art of that century: if national identity is a myth, or at least a construction, it is a construction that nineteenthcentury artists and their audiences often believed in, built their expectations on and sometimes tried to live up to.

If the adoption of a national research perspective can gain some validation on these grounds, it nevertheless remains a fact that the importance of international transfers in the nineteenth-century art market can hardly be overestimated. A number of publications have, as a result, paid attention to this international dimension of the market, usually on the basis of individual case studies. Often, they discuss either the commercial relations between two nationally circumscribed art communities, with one usually framed as dominant (Paris, London) and the other as peripheral; or, alternatively, they deal with the import and promotion of a specific type of foreign art production in a nationally defined market. ${ }^{19}$ These studies have contributed greatly to a more internationally oriented understanding of national markets and were a source of inspiration for the present volume. Even in these studies, however, the international is usually an accessory to the national rather than an essential and defining element. What is still lacking is an overall understanding of, or an overarching argument on, the international dynamic of the art market as a whole-or at least the art market in the West. Such an argument would have to examine the geographically divergent social, political and economic contexts that formed the breeding ground of the increasing internationalisation of the art market as well as its effects on producers, consumers and middlemen. It would have to analyse the parts played by these various actors, whether in response to broader market developments or by actively making or shaping the market. It would also need to address the complex interplay between the national and the international, for indeed both often appear to have been two sides of the same coin in this dynamic.

Substituting a national perspective for a more international view is, however, a delicate undertaking and entails various problems and difficulties.

19 See for instance the excellent essays collected under the title 'Paris et l'Europe: Mouvements des modes, diffusions des connaissances' in: Monica Preti-Hamard and Philippe Sénéchal, eds., Collections et marché de l'art en France 1789-1848 (Rennes: Presses universitaires de Rennes, 2005), 283-430. 
The most obvious and practical difficulty is that it is virtually impossible to become profoundly acquainted with the large number of national art scenes that would have to be studied extensively in order to fully develop such an allencompassing approach. This is the reason why the different case studies that form the bulk of this volume still focus on international aspects of national art scenes. This is also why this volume, while striving for a truly international perspective, takes its material mainly from the French, British, Belgian and Dutch art worlds, with an occasional excursion to the German and the burgeoning North American markets. Nevertheless, taken together, we hope that the different contributions in this book will constitute a first step in the direction of an international history of the nineteenth-century Western art market.

On a more fundamental level, the most important risk of an international or transnational approach is to lose sight again of the contexts and developments specific to national circumferences. One example may make this clear. Despite astute criticism, Harrison and Cynthia White's famous notion of the 'dealer critic system' is arguably still the closest we have come to a master narrative of the history of the nineteenth-century market for modern art. ${ }^{20}$ Attempts have been made to relate their concept to other national contexts than the French, for which the Whites originally intended it. These studies have added a comparative perspective to art market research and have sometimes even been able to identify flaws in, or add nuance to, the Whites' theory. ${ }^{21}$ An international dynamic undoubtedly played a role in some of the developments described by the Whites (leaving aside the validity of their conclusions for now). The increasing presence of foreign artists at the annual French Salons, for instance, unquestionably put more pressure on the existing Salon-Academy system, thus making the reform of the French art world more urgent and possibly contributing to art dealers' rise to power. It is another thing, however, to simply apply the Whites' ideas to other national circumscriptions. Indeed, a simple transplantation of the notion of the 'dealer critic system' to other national

20 Harrison C. and Cynthia A. White, Canvases and Careers: Institutional Change in the French Painting World (Chicago - London: The University of Chicago Press, 1993). See for the most thorough critique of the Whites' understanding of the French art market: David W. Galenson and Robert Jensen, "Careers and Canvases: The Rise of the Market for Modern Art in Nineteenth-Century Paris," Van Gogh Studies 1 (2007): 137-66.

21 Jan Dirk Baetens, "Vanguard Economics, Rearguard Art: Gustave Coûteaux and the Modernist Myth of the Dealer-Critic System," Oxford Art Journal 33, no. 1 (2010): 25-41; Pamela Fletcher and Anne Helmreich, "The Periodical and the Art Market: Investigating the 'Dealer-Critic System' in Victorian England," Victorian Periodicals Review 41, no. 4 (2008): 323-51; Chris Stolwijk, Uit de schilderswereld. Nederlandse kunstschilders in de tweede helft van de negentiende eeuw (Leiden: Primavera, 1998), 20-1. 
contexts may change the very meaning of the concept. The specific institutional constellation that the Whites had in mind when coining the notion of the 'dealer critic system' was, in their thinking, both a reaction to and a result of the bankruptcy of the French academic system. This academic system, however, was never as powerful and dominant in other European countries as it was in France. Pointing at phenomena in other countries that seem related to what the Whites designated as the 'dealer critic system,' therefore, either calls for another label or for a complete revision of the history of the market as sketched by the Whites, including perhaps a rejection of their terminology as a whole.

\section{Knowledge and Networks across Boundaries}

The present collection offers neither a new master narrative of the development of the nineteenth-century art market nor, more modestly, of the internationalisation of the art market. However, it does attempt to sketch out some of the lines that such an overarching narrative could follow or weave together. Central in this volume is the idea that new modes or structures of knowledge were crucial for the international expansion of the art market. More in particular, this volume studies the gradual rise of an international economy of art knowledge (both artistic and commercial) in which, firstly, local and regional knowledge coagulated in institutions and networks through which that knowledge was progressively transferred across borders; and secondly, in which categories and concepts based on ideas of national identity became increasingly important and, paradoxically, facilitated rather than obstructed the internationalisation of the nineteenth-century art market. It is this volume's contention that this dialectical process of, on the one hand, the rising emphasis in art discourse and art knowledge on national identity and, on the other, the international expansion of the art market, was one of the defining characteristics of the development of the Western art world(s) during the "long" nineteenth century.

In our introductory chapter, we first trace the internationalisation of the European art world from a chronologically and geographically broad perspective and pay attention to the different ways in which this process affected the production, distribution and consumption of art. On this basis, we subsequently set out to develop our overarching argument on the quintessential importance of new modes of art knowledge based on national categories in this process of market integration. Thus, the stage is set for the other chapters, which focus on more time- and place-specific case studies. They deal with 
structures of knowledge, information networks and the fields of tension created by them, all conceived along the two complementary axes of national identity and international exchange.

The chapters by Bénédicte Miyamoto and Leanne Zalewski address specific instances where new structures of knowledge emerged in dialectical relationship with the art market. Miyamoto chronologically captures the eighteenthcentury transformation of the auction catalogue from a mere advertisement to an educational tool for a new generation of art lovers. British catalogues, with a growing discursive shift towards schools, manners and genres, offered their readers a carefully constructed conceptual framework and vocabulary to think and talk about paintings. Zalewski paints a similar picture for late nineteenthcentury New York, where collection, auction and exhibition catalogues not only supported the education of American auction and exhibition visitors, but they also produced social and cultural capital for collectors who could present themselves as cosmopolitan and sophisticated because of their acquaintance with European high culture. Zalewski's close reading of these catalogues and their references to foreign schools, honours and career trajectories reveals how knowledge was constructed in order to meet the different purposes that prestigious international art collections served in the burgeoning American art market of the late nineteenth century. Together, both chapters also demonstrate that catalogues are a much-underestimated force in structuring art knowledge in general and were indeed crucial in solidifying the categories of national artistic schools in the nineteenth-century art market in particular.

The new structures of knowledge that were designed and fine-tuned in the course of the nineteenth century not only served the market, in the strict sense of the word, in that they accommodated the transfer of works of art across borders, but they also affected the market in a broader sense and left their traces, for instance, on the modes of production and consumption of art. In her contribution Barbara Pezzini shows how the strong intertwinement of the art market and the knowledge market helped British artists in the early twentieth century to construct their own national identities and at the same time affected the reception of the work they produced. She explains how British artists saw their markets threatened as advanced French art became increasingly en vogue in the London art scene of the 19oos, with Roger Fry's 1910 post-impressionist exhibition as a key moment. Inspired by the concomitant boom of the old masters market, however, British artists turned to the examples of these old masters to construe a pan-European, eclectic artistic identity for themselves and thus face the challenges of an internationalising art world. 
Pezzini's research also draws attention to the ways in which the production, distribution and use of informational categories were embedded in crystallised information networks that included artists, critics, art historians and dealers. These networks are the focal point of the second cluster of contributions to this volume. Their importance is beautifully illustrated in Pezzini's discussion of the Burlington Magazine, an art periodical at the crossroads of criticism, commerce and artistic practice, supported by a diverse group of people who attempted to promote contemporary British artists by inscribing them in a framework of national and foreign artistic references. In her chapter Camilla Murgia also shows the strength of a diversified network in promoting national schools with her analysis of the Italian artistic community in London around 1800 and its success in creating a niche market for Italian prints. The strength of this particular community was the intense collaboration between print makers, publishers and sellers, with the expatriated Tuscan engraver and art dealer Francesco Bartolozzi at its core, and the vertical business integration that ensued from it. A different example of the importance and strength of knowledge networks in an internationalising art scene is developed by Lukas Fuchsgruber, who provides us with a fascinating insight into the functioning of international horizontal networks in the nineteenth-century art world. In his comparative study of, firstly, German dealers Louis and Rudolf Lepke and, secondly, Otto Mündler, he illustrates how different kinds of horizontal networks facilitated different types of international transfers. While the Lepke dealership put their stakes on a comparatively linear model of exchange between Berlin and Paris, Mündler developed a much broader network that allowed him to exchange knowledge and facilitate the exchange of artistic goods on a much ampler international scale.

The crucial role of networks in international transfers is also underlined in Adriana Turpin's chapter. She observes that first French and later British networks not only imported Ancien Régime furniture from the Continent into England, but they also functioned as conductors for the transmission of knowledge on artistic skills and craftmanship in the decorative arts. International networks thus facilitated the transfer of art and antiques across borders, but also that of art knowledge, which was vital to the further integration of the European art world.

However, the increasing integration of art markets in the age of nation states and the central role of concepts and categories derived from nationalist thinking in the accompanying international knowledge economy could also create complex fields of tension that had to be negotiated carefully by actors operating in the international market. These fields are studied in a third 
cluster of contributions to this volume. Turpin's article further explores this unavoidable and indeed inherent friction between the forces of nationalism and internationalism in her analysis of the long-lasting success in England of French furniture in an era dominated by_often anti-French — British nationalism. She shows how the adoption of the French foreign style in a period of intense national British pride must be paradoxically framed as an expression of British cosmopolitanism: by appropriating the art of their enemy, British plutocrats were at the same time British and international. In her essay on sculptor Medardo Rosso, Sharon Hecker also examines the tension field created between an internationalised art world and the enduring importance of national interests and nationalist thinking, now from the perspective of an ambitious artist trying to carve out a place for himself in an expanded art world. She shows how Rosso, as a foreign sculptor, attempted to negotiate cultural differences between the different national art scenes that he set out to conquer, exhibiting an outspoken internationalist attitude but also capitalising on his own Italian background and training. In a final contribution, Robert Verhoogt demonstrates how the same tension field between the national and the international affected the vital nineteenth-century print market. He describes how national differences and interests could obstruct the efficient integration of different national markets and how, conversely, international trade could threaten national markets and its players. In addition, he shows how dealers could succeed in reconciling international trade and nationalist discourse, which now no longer opposed but mutually reinforced one another.

Throughout these nine contributions, accommodated in three multiconnected clusters, a common thread emerges. The first cluster concerns the formation of art knowledge in national markets; the second deals with the grounding and circulation of this knowledge in both horizontal and vertical networks; and the third cluster focuses on the negotiation by different actors of the field of tension created by the uneasy relation between international trade and the discourse of national identity that accompanied it. The conclusion that follows from this volume is that the economy of knowledge was a vital precondition to the economy of goods, that knowledge based on national categories lay — paradoxically —at the heart of the market's internationalisation, but also that it created tensions that would eventually necessitate a new cosmopolitan and even global discourse.

All of this, however, is merely a first and modest step towards an international history of the nineteenth-century art trade. In a concluding epilogue, therefore, Pamela Fletcher and Anne Helmreich attempt to move beyond the case study methodology of the volume's contributions. They point out new directions that future research may explore, examining issues related to the 
terms "international," "art" and "market." They end their epilogue with what they call 'a provocation:' a model for future research of the international art market. We can only hope that this challenge will soon be taken up.

\section{References}

Anon. Nieuwen almanach der konst-schilders, vernissers, vergulders en marmelaers. Ghent: s.n., [c. 1777].

Baetens, Jan Dirk. "Vanguard Economics, Rearguard Art: Gustave Coûteaux and the Modernist Myth of the Dealer-Critic System." Oxford Art Journal 33, no. 1 (2010): 25-41.

Bayer, Thomas M., and John R. Page. The Development of the Art Market in England: Money as Muse, 1730-19oo. London: Pickering \& Chatto, 2011.

Corbeau-Parsons, Caroline, ed. Impressionists in London: French Artists in Exile 18701904. London: Tate, 2018.

Cornelis, Bart. "Arnold Houbraken's Groote Schouburgh and the Canon of SeventeenthCentury Dutch Painting." Simiolus: Netherlands Quarterly for the History of Art 26, no. 3 (1998): 144-61.

De Marchi, Neil, and Hans J. Van Miegroet. "Novelty and Fashion Circuits in the MidSeventeenth-Century Antwerp-Paris Art Trade." Journal of Medieval and Early Modern Studies 28, no. 1 (1998): 201-46.

De Marchi, Neil, and Hans J. Van Miegroet. "Transforming the Paris Art Market, 1718-1750." In Mapping Markets for Paintings in Europe, 1450-1750, edited by Neil De Marchi and Hans J. Van Miegroet, 391-402. Turnhout: Brepols, 2006.

Durand-Ruel, Paul. Memoirs of the First Impressionist Art Dealer (1831-1922). Paris: Flammarion, 2014.

Fletcher, Pamela M., and Anne Helmreich. "The Periodical and the Art Market: Investigating the 'Dealer-Critic System' in Victorian England." Victorian Periodicals Review 41, no. 4 (2008): 323-51.

Fletcher, Pamela M., and Anne Helmreich, eds. The Rise of the Modern Art Market in London, 1850-1939. Manchester - New York: Manchester University Press, 2011.

Galenson, David W., and Robert Jensen. "Careers and Canvases: The Rise of the Market for Modern Art in Nineteenth-Century Paris." Van Gogh Studies 1 (2007):137-66.

Glorieux, Guillaume. À l'enseigne de Gersaint: Edme-François Gersaint, marchand d'art sur le pont Notre-Dame (1694-1750). Seyssel: Champ Vallon, 2002.

Jensen, Robert. Marketing Modernism in Fin-de-Siècle Europe. Princeton: Princeton University Press, 1994.

Lammertse, Friso, and Jaap van der Veen. Uylenburgh \& Son: Art and Commerce from Rembrandt to De Lairesse 1625-1675. Zwolle: Waanders, 2006. 
Lyna, Dries. "Towards an Integrated Market? The Austrian Netherlands and the Western European Trade in Pre-Owned Paintings." In Moving Pictures: Intra-European Trade in Images, 16th-18th Centuries, edited by Neil De Marchi and Sophie Raux, 277-88. Turnhout: Brepols, 2014.

Michel, Patrick. "French Collectors and the Taste for Flemish Painting During the Eighteenth Century." In Art Auctions and Dealers: The Dissemination of Netherlandish Art During the Ancien Régime, edited by Dries Lyna, Filip Vermeylen, and Hans Vlieghe, 127-37. Turnhout: Brepols, 2009.

Montias, John Michael. Art at Auction in Seventeenth-Century Amsterdam. Amsterdam: Amsterdam University Press, 2002.

Ormrod, David. "Dealers, Collectors and Connoisseurship in Seventeenth \& EighteenthCentury London 1660-176o." In Kunstsammeln und Geschmack im 18. Jahrhundert, edited by Michael North, 15-23. Berlin: Berliner Wissenschafts-Verlag, 2002.

Pomian, Krzystzof. "Marchands, connaisseurs, curieux à Paris au XVIII e siècle." Revue de l'art 43 (1979): 23-36.

Preti-Hamard, Monica, and Philippe Sénéchal, eds. Collections et marché de l'art en France 1789-1848. Rennes: Presses Universitaires de Rennes, 2005.

Stolwijk, Chris. Uit de schilderswereld. Nederlandse kunstschilders in de tweede helft van de negentiende eeuw. Leiden: Primavera, 1998.

Szanto, Mickaël. "Antwerp and the Paris Art Market in the Years 1620-1630." In Mapping Markets for Paintings in Europe, 1450-1750, edited by Neil De Marchi and Hans J. Van Miegroet, 329-42. Turnhout: Brepols, 2006.

Vermeylen, Filip. "À la recherche de l'art vendu: la diffusion de la peinture flamande en France (16ième-18ième siècle)." In Collectionner dans les Flandres et la France du Nord au XVIII ${ }^{e}$ siècle, edited by Sophie Raux, 127-38. Lille: Université Charles-deGaulle-Lille, 2003.

Van Ginhoven, Sandra. Connecting Art Markets: Guilliam Forchondt's Dealership in Antwerp (c. 1632-78) and the Overseas Paintings Trade. Boston: Brill, 2016.

White, Harrison C., and Cynthia A. White. Canvases and Careers: Institutional Change in the French Painting World. Chicago - London: The University of Chicago Press, 1993. 